\title{
Stress Experiences and Management Among University of Bohol CHMTN Junior Students
}

\author{
REINALDA JOSEPHINE O. GAMUTAN \\ rjogamutan@universityofbohol.edu.ph \\ ORCID No. 0000-0003-3910-7908
}

\section{MA. CHALMANE L. AÑORA}

chalmaneanora96@gmail.com

ORCID No. 0000-0001-5371-1672

PAULINE BERNADETE P. JALA

paulinebernadetejala@yahoo.com

ORCID No. 0000-0002-9088-4254

\section{STEVEN JAY V. MISSION}

stevenjaymission@yahoo.com

ORCID No. 0000-0001-5294-313X

\section{RENEVIC D. MURING}

renmhurs@gmail.com

ORCID No. 0000-0001-8218-5843

\section{KENT RIAN T. PINAR}

doxo_kent@yahoo.com

ORCID No. 0000-0003-3898-7771

\section{ABSTRACT}

The term 'stress' generally refers to the response of a person when he is in a situation that forces him to act, change or adjust in order for him to be in balance or maintain footing. Stress can make students sick and 
can affect their feelings, thoughts, personalities and performance. Thus, it is essential to ensure that they have the necessary skills and appropriate attitude in dealing with various school activities and school-related stress. It is the researcher's objective to identify the stressors that affect the lifestyle of the third year students of the College of Hospitality Management, Tourism and Nutrition (CHMTN), and the mechanisms they practice to manage stress. Quantitative method of research was used with the aid of questionnaires. The data gathered were statistically treated making use of weighted means, composite means and analysis of variance. The respondents included 80 students $(82.47 \%)$ from the three courses of the CHMTN namely BSHRM, BSTM AND BSND. Results showed composite means of Sometimes Affected (SA), Sometimes Manifested (SM), and Sometimes Elicited (SE) for the three respective areas of School-related Stress Experiences; Sometimes Affected (SA) for Stress in relation to the students' studies, school performance, mood and relationship to family, friends and community; and, Sometimes Applied (SA) for Stress Management Techniques. The outcome of the study served as a guide in constructing intervention measures.

\section{KEYWORDS}

Stress Experiences, Stress Management, UB CHMTN Junior Students, Quantitative Method, Philippines

\section{INTRODUCTION}

The term 'stress' generally refers to the response of a person when he is in a situation that forces him to act, change or adjust in order for him to be in balance or maintain footing. The situations themselves are considered the 'stressors' (Townsend, 2014).

Stress can affect one's health condition. It influences one's feelings, thoughts, and behavior. Thus, it is important to recognize the significant relationship between one's body and mind. A critical recognition of these interactions is the understanding that modern diseases are complicated by extreme emotional disturbances (Cohen, 2004).

The student is supposed to possess the necessary preparation, attitude, and skills in order to have a successful student life. He must be 
ready to face all challenges given by the professors, classmates, friends and family. Furthermore, he must know how to strike a balance between bestowed responsibilities and the usual tasks throughout his student life. It is necessary to develop the right attitude even with a heavy strain added on his back (Mulford, 2008).

College requires significantly more efforts from students than high school. Once you enter college, professors are more demanding, students are more motivated, and expected to be more independent. It is common for college students to experience greater levels of stress related to academics as a result of new demands. Higher academic standards and expectations are even more evident in graduate school (Hanson et al., 2010).

The main purpose of the study was to determine the stress experienced and the management undertaken among junior students of the College of Hospitality Management, Tourism and Nutrition.

Specifically, it aimed to answer the following sub-questions:

1. What is the profile of the student respondents in the context of:

1.1 Age

1.2 Gender

2. On School-Related Stress Experiences

2.1 What school-related stressors are the students exposed recently?

2.2 What signs and manifestations of stress are the students experiencing?

2.3 What behaviors are the students eliciting as an effect/s of their school related-stress?

2.4 What are the students' perceptions on school-related stress as affecting their studies, school performance, mood and interpersonal relationships?

3. What stress management techniques are the students applying?

4. What intervention measures can be proposed on the basis of the findings?

In general, college students are confronted with challenges and difficulties that when taken negatively will administer unfavourable effect on their performance (Felsten and Wilcox, 1992; Pritchard and Wilson, 2003; Russell and Petrie, 1992) resulting to helplessness (Abramson et. al, 1980; Sedek and Kofta, 1990), depression, and eventually stress 
(Carver and Scheier, 1994). More often, they experience various stresses especially in an entirely new social environment with greater freedom and less or no adult supervision at all (Lefkowitz, 2005), homesickness, a sense of isolation, and increased interpersonal conflict (Buote et al., 2007).

The Cognitive Appraisal Theory of Lazarus also mentions a two-way process in assessing the threat tendency of stress to a person and how he reacts to the stressors namely: primary appraisal which involves analyzing whether an occurred event is harmful or a challenging one, and secondary appraisal, which involves dealing with stressor or the stress it produces (Mandler, 2003).

As Blankstein (2004) emphasized, keeping one's body tension-free is the best way to combat stress because if the body is free from stress, the mind gravitates to relax.

A quantitative method was used in this study using appropriate statistical treatment using the universal random sampling.

After securing a final list of the CHMTN Junior Students from the university registrar's office, a letter of intent was sent to the department Dean and Dean of Student Personnel Services asking permission to distribute questionnaires and conduct the study to the target respondents. Questionnaires were then distributed to the students concerned on specified dates. For the ethical consideration of the study, ethics review was conducted by the UB-REB.

Gathered data were collated in tables.

\section{FINDINGS AND RESULTS}

The gathered data are herein presented, analyzed and interpreted in the light of the various aspects of the problem. 


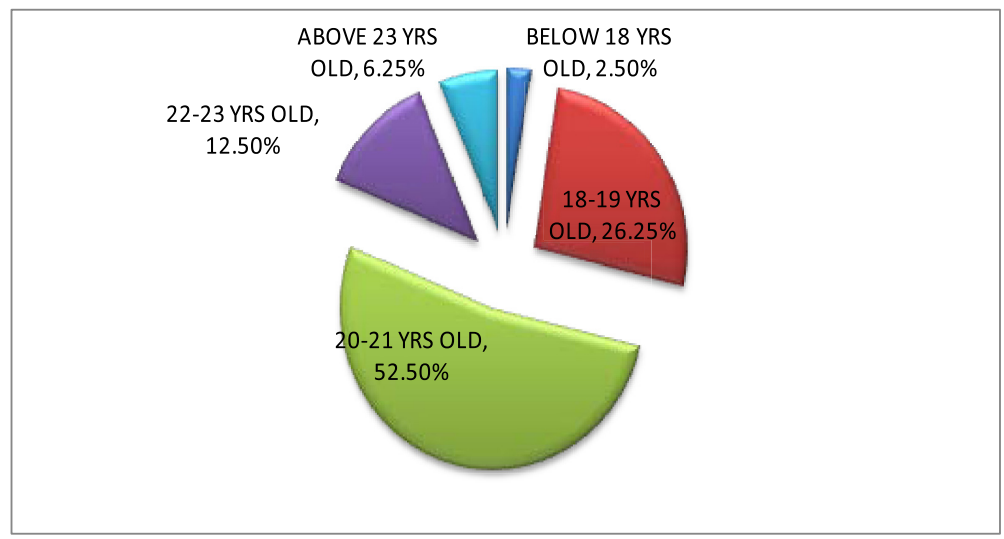

\section{GRAPH I - A. AGE}

As viewed from the graph above, 52.50 percent of the UB CHMTN Junior Students are from 20-21 years old which ranked the highest, and the youngest group wasbelow 18 years oldwith 2.5 percent.

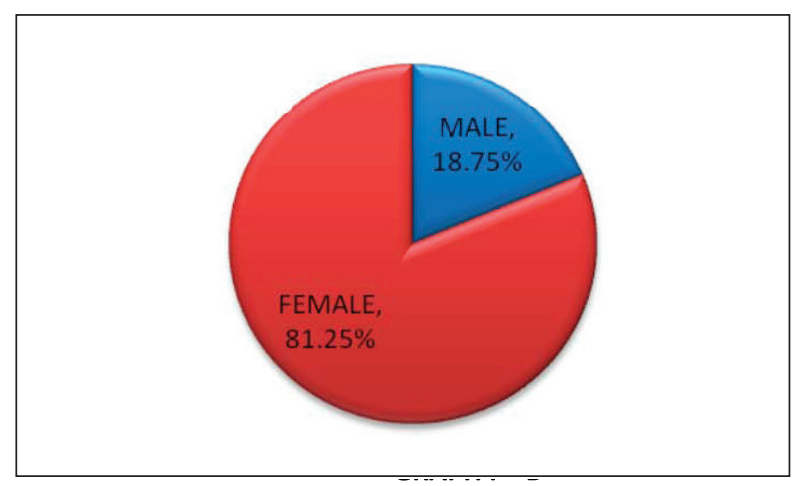

\section{GRAPH I - B. GENDER}

Among the respondents, 81.25 percent or 65 out of 80 respondents were female and only 18.75 percent or 15 out of 80 respondents were male. 


\section{School - Related Stress Experiences}

Table I - A reveals school - related stress experiences which include the stressors (Table I-A1), their signs and/or manifestations (Table I-A2) and the students' behaviors elicited as effects of these stressors (Table I-A3). On the other hand, Table I - B shows the students' perception of school - related stressors as affecting their studies, school performance, mood, and relationship to family, friends, and community.

TABLE I - A

SCHOOL - RELATED STRESS EXPERIENCES

$\mathrm{N}=(80)$

\begin{tabular}{|l|c|l|c|}
\hline $\begin{array}{l}\text { Table I-A1. What school- } \\
\text { related stressors do you } \\
\text { think are affecting you } \\
\text { recently? }\end{array}$ & WM & \multicolumn{1}{|c|}{ DV } & Rank \\
\hline 1. Subject & 2.47 & Always Affected & 3 \\
\hline 2. Classmate & 1.9 & Sometimes Affected & 6 \\
\hline 3. Schoolmate & 1.62 & Not Affected & 7 \\
\hline 4. Instructor/Teacher & 2.47 & Always Affected & 3 \\
\hline 5. Project/ Assignment & 2.58 & Always Affected & 1 \\
\hline 6. Campus atmosphere & 1.99 & Sometimes Affected & 4 \\
\hline 7. Tuition Fee & 2.5 & Always Affected & 2 \\
\hline 8. Classroom & 1.91 & Sometimes Affected & 5 \\
\hline 9. Facilities & 1.99 & Sometimes Affected & 4 \\
\hline Composite Mean & $\mathbf{2 . 1 6}$ & Sometimes Affected & \\
\hline
\end{tabular}

The following are the results of the survey: project and assignment, 2.58 or Always Affected; schoolmate, 1.62 or Not Affected. .

\begin{tabular}{|l|c|l|c|}
\hline $\begin{array}{l}\text { Table I-A2. Which of } \\
\text { the following signs and } \\
\text { manifestations of stress are } \\
\text { you experiencing? }\end{array}$ & WM & DV & Rank \\
\hline 1. Insomnia & 2.10 & Sometimes Manifested & 6 \\
\hline 2. Headache & 2.11 & Sometimes Manifested & 5 \\
\hline
\end{tabular}




\begin{tabular}{|c|c|c|c|}
\hline 3. Eating more or less & 2.24 & Sometimes Manifested & 3 \\
\hline 4. Anxiety & 1.97 & Sometimes Manifested & 8 \\
\hline 5. Moody swings & 2.15 & Sometimes Manifested & 4 \\
\hline 6. Upset stomach & 1.87 & Sometimes Manifested & 9 \\
\hline 7. Poor judgment & 1.99 & Sometimes Manifested & 7 \\
\hline 8. Lack of concentration & 2.34 & Always Manifested & 1 \\
\hline 9. Lack of motivation & 2.34 & Always Manifested & 1 \\
\hline 10.Constant worrying & 2.33 & Always Manifested & 2 \\
\hline Composite Mean & 2.14 & Sometimes Manifested & \\
\hline
\end{tabular}

These stress manifestations were identified and rated by the UB CHMTN Junior Students as follows: lack of concentration and lack of motivation, 2.34 or Always Manifested; upset stomach, 1.87 or Sometimes Manifested. The composite mean turned out to be 2.14 which is interpreted as Sometimes Manifested.

\begin{tabular}{|l|c|l|c|}
\hline $\begin{array}{l}\text { Table I-A3. Which of the } \\
\text { following behavior/s do you } \\
\text { experience as an effect/s of } \\
\text { your school-related stress? }\end{array}$ & WM & \multicolumn{1}{|c|}{ DV } & Rank \\
\hline 1. Lack of sleep & 2.41 & Always Elicited & 1 \\
\hline 2. Prone to anger & 2.25 & Sometimes Elicited & 2 \\
\hline 3. Tardiness in class & 2.15 & Sometimes Elicited & 3 \\
\hline 4. Memory gap & 2.1 & Sometimes Elicited & 4 \\
\hline 5. Excessive eating & 2.03 & Sometimes Elicited & 5 \\
\hline 6. Depression & 2 & Sometimes Elicited & 6 \\
\hline 7. Less efficient & 1.97 & Sometimes Elicited & 7 \\
\hline 8. Class Absenteeism & 1.97 & Sometimes Elicited & 7 \\
\hline 9. Poor performance in school & 1.96 & Sometimes Elicited & 8 \\
\hline 10. Poor health & 1.77 & Sometimes Elicited & 9 \\
\hline Composite Mean & $\mathbf{2 . 0 6}$ & Sometimes Elicited & \\
\hline
\end{tabular}


The table on behavioral effects of stress was rated by the Junior Students as: lack of sleep, 2.41 or Always Elicited; poor health, 1.77 or Sometimes Elicited. The overall composite mean is 2.06 or Sometimes Elicited.

\section{TABLE I - B}

Students' Perception on School - Related Stress as Affecting Their Studies, School Performance, Mood And Relationship to Family, Friends and Community

\begin{tabular}{|l|c|c|c|}
\hline & WM & Interpretation & Rank \\
\hline $\begin{array}{l}\text { 1. Do you feel school-related stress } \\
\text { affect your study? }\end{array}$ & 2.42 & Always Affected & 1 \\
\hline $\begin{array}{l}\text { 2. Does the school-related stress } \\
\text { affect your school performance? }\end{array}$ & 2.38 & Always Affected & 2 \\
\hline $\begin{array}{l}\text { 3. Does the school-related stress } \\
\text { affect your mood? }\end{array}$ & 2.38 & Always Affected & 2 \\
\hline $\begin{array}{l}\text { 4. Does the school-related stress } \\
\text { affect your relationship to your } \\
\text { family? }\end{array}$ & 1.63 & Not Affected & 5 \\
\hline $\begin{array}{l}\text { 5. Does the school-related stress } \\
\text { affect your relationship to your } \\
\text { friends? }\end{array}$ & 1.94 & Sometimes Affected & 3 \\
\hline $\begin{array}{l}\text { 6. Does the school-related stress } \\
\text { affect your relationship to your } \\
\text { community? }\end{array}$ & 1.9 & Sometimes Affected & 4 \\
\hline Composite Mean & $\mathbf{2 . 1 1}$ & Sometimes Affected & \\
\hline
\end{tabular}

The following perceptions were identified regarding school-related stress: stress affect the students' study, 2.42 or Always Affected; stress affecting relationship to the family, 1.63 or Not Affected. A composite mean or 2.11, Sometimes Affected, was obtained.

\section{Stress Management}

Some stress management techniques applied to overcome or reduce stress. 
TABLE II

Student' Stress Management

\begin{tabular}{|l|c|c|c|}
\hline $\begin{array}{l}\text { Stress Management } \\
\text { Techniques }\end{array}$ & WM & DV & Rank \\
\hline 1. Took a rest & 2.73 & Always Applied & 1 \\
\hline 2. Listened to music & 2.57 & Always Applied & 2 \\
\hline $\begin{array}{l}\text { 3. Watched comedy videos/ } \\
\text { movies }\end{array}$ & 2.54 & Always Applied & 3 \\
\hline $\begin{array}{l}\text { 4. Called or talked to a friend } \\
\begin{array}{l}\text { 5. Rewarded yourself with } \\
\text { leisure activities }\end{array}\end{array}$ & 2.44 & Always Applied & 4 \\
\hline $\begin{array}{l}\text { 6. Went for a walk and spent } \\
\text { time with nature }\end{array}$ & 2.01 & Sometimes Applied & 5 \\
\hline 7. Played with a pet & 1.91 & Sometimes Applied & 7 \\
\hline $\begin{array}{l}\text { 8. Played a musical instrument } \\
\text { 9. Go to a party }\end{array}$ & 1.85 & Sometimes Applied & 8 \\
\hline $\begin{array}{l}\text { 10. Wrote a journal or } \\
\text { compose poem }\end{array}$ & 1.63 & Not Applied & 9 \\
\hline Composite Mean & $\mathbf{2 . 1 3}$ & Sometimes Applied & 6 \\
\hline
\end{tabular}

The stress management techniques applied were as follows: Took a rest, 2.73 or Always Applied; wrote a journal or poem, 1.51 or Not Applied and the composite mean, 2.13 or Sometimes Applied.

\section{CONCLUSIONS}

1. Among school-related stressors, projects and assignments came out as the most common.

2. On the other hand, lack of concentration and lack of motivation were the most common signs and symptoms experienced by the students while upset stomach was the least experienced.

\section{RECOMMENDATIONS}

1. Teachers should assign projects allowing enough time for the students to comply. Students as well should be conscious with the deadlines of 
their deliverables to avoid cramming and stress.

2. The Student Affairs Office should conduct symposiums, workshops or structured learning activity (SLE) on stress/time management both to students and teachers.

3. Students should acquire sufficient knowledge on time management to balance extra-curricular or co-curricular activities with academics.

\section{LITERATURE CITED}

Abramson, L. Y., Garber, J., and Seligman, M. E. P. (1980). Learned helplessness in humans: an attributional analysis. In J. Garber and M. E. P. Seligman (eds.), Human Helplessness: Theory and Application, pp. 3-34. New York: Academic Press. Retrieved January 2, 2015, from https://goo.gl/ySHHsD

Blankstein, A. M. (2004). Failure is not an option: Six principles that guide student achievement in high-performing schools. Corwin Press. Retrieved January 2, 2015, from https://goo.gl/4qSM8p

Buote, V. M., Pancer, S. M., Pratt, M. W., Adams, G., Birnie-Lefcovitch, S., Polivy, J., \& Wintre, M. G. (2007). The importance of friends: Friendship and adjustment among 1st-year university students. Journal of Adolescent Research, 22, 665-689. doi:10.1177/0743558407306344 Retrieved January 2, 2015, from https://goo.gl/kJQ8YV

Carver, C. S., and Scheier, M. F. (1994). Situational coping and coping dispositions in a stressful transaction. Journal of Personality and Social Psychology 66: 184-195. Retrieved January 2, 2015, from https://goo.gl/qub1qX

Cohen, S. (2004). Social relationships and health. American psychologist, 59(8), 676. Retrieved December 15, 2014, from https://goo.gl/dz5CAL

Felsten, G., and Wilcox, K. (1992). Influences of stress and situationspecific mastery beliefs and satisfaction with social support on wellbeing and academic performance. Psychological Reports 70(1): 291303. Retrieved December 15, 2014, from https://goo.gl/NR8r1B 
Hanson, T. L., Drumheller, K., Mallard, J., McKee, C., \& Schlegel, P. (2010). Cell phones, text messaging, and Facebook: Competing time demands of today's college students. College teaching, 59(1), 23-30. Retrieved December 15, 2014, from https://goo.gl/F8q98u

Lefkowitz, E. S. (2005). "Things have gotten better": Developmental changes among emerging adults after the transition to university. Journal of Adolescent Research, 20, 40-63. doi:10.1177/0743558404271236 Retrieved December 15, 2014, from https://goo.gl/e7Yfge

Mandler, G. (2003). Emotion. Handbook of psychology. Retrieved February 2, 2015, from https://goo.gl/PrM3A7

Mulford, B. (2008). The leadership challenge: Improving learning in schools. Retrieved February 2, 2015, from https://goo.gl/jA9z3N

Pritchard, M. E., and Wilson, G. S. (2003). Using emotional and social factors to predict student success. Journal of College Student Development 44(1): 18-28. Retrieved February 2, 2015, from https:// goo.gl/zeWnyy

Russell, R.K., and Petrie, T.A. (1992). Academic adjustment of college students: Assessment and counseling. In: Lent, R. W. (eds.), Handbook of Counseling Psychology, 2nd nd edition, John Wiley and Sons, Inc, Hoboken, NJ, pp. 485-511. Sandler, M. E. (2000a). Career decisionmaking self-efficacy, perceived Retrieved December 15, 2014, from https://goo.gl/kNGPNS

Sedek, G., and Kofta, M. (1990). When cognitive exertion does not yield cognitive gain: toward an informational explanation of learned helplessness. Journal of Personality and Social Psychology 58: 729743. Retrieved December 15, 2014, from https://goo.gl/iW5PF1

Townsend, M. C. (2014). Psychiatric mental health nursing: Concepts of care in evidence-based practice. FA Davis. Retrieved December 15, 2014, from https://goo.gl/Ncg15w 